\title{
On Two Nematodes from Brazilian Birds and Description of a New Species (Acuarioidea, Schistorophinae) Parasitizing Laterallus viridis (Müller, 1776) (Gruiformes, Rallidae)
}

\author{
Roberto Magalhães Pinto ${ }^{+}{ }^{++}$, Joaquim Júlio Vicente ${ }^{++}$, Luís C Muniz-Pereira, \\ Dely Noronha ${ }^{+++}$
}

Laboratório de Helmintos Parasitos de Vertebrados, Departamento de Helmintologia, Instituto Oswaldo Cruz, Av. Brasil 4365, 21045-900 Rio de Janeiro RJ, Brasil

The present paper reports acuarioid nematodes recovered from avian hosts. A new species of the genus Schistorophus Railliet, 1916 is proposed based mainly on findings referring to ptilina, spicules and vagina. Ancyracanthopsis coronata (Molin, 1860) Chabaud \& Petter, 1959 is referred again in Brazil since its proposition in 1860, from specimens recovered from a Brazilian bird. A revised key to the species of the genus Schistorophus is also presented.

Key words: nematoda - Schistorophus - new species - Ancyracanthopsis - morphometrics - birds - Brazil

Investigations related to avian nematodes have been our main interest for several years. The scope of the present approach is to provide additional data on the knowledge of nematodes parazitizing Brazilian birds, since these parasites have recently been accounted in a complete and extensive review from 1788 to 1995 (Vicente et al. 1995). The results presented herein refer to acuarioid nematodes, with a proposal of a new species of the genus Schistorophus Railliet, 1916, and an analysis of morphometric parameters of Ancyracanthopsis coronata (Molin, 1860 a) Chabaud and Petter, 1959. This species, described from specimens recovered from a Brazilian host, has only been reported in foreign countries since its original description in 1860.

\section{MATERIALS AND METHODS}

Nematodes were recovered from two avian species: Laterallus viridis (Müller, 1776) [= Rallus cayennensis (Gmelin)] in November, 1909 and Aramides mangle (Spix, 1825) in August, 1940 by Gomes de Faria and D Machado Filho, respectively. Samples were preserved in Railliet \& Henry's solution $(0.85 \% \mathrm{NaCl}$ solution: $93 \mathrm{ml}$; formaldehyde: 5 $\mathrm{ml}$; glacial acetic acid: $2 \mathrm{ml}$ ) and deposited in the

\footnotetext{
${ }^{+}$Corresponding author. Fax: +55-21-260.4866. E-mail: rmpinto@gene.dbbm.fiocruz.br

${ }^{++}$Research fellow CNPq

${ }^{+++}$Curator of the CHIOC/IOC

Received 15 December 1998

Accepted 16 July 1999
}

Helminthological Collection of the Oswaldo Cruz Institute (CHIOC). Processing of the helminths for study, photomicrographs and illustrations were obtained as described elsewhere (Pinto et al. 1993, Pinto \& Vicente 1995). Measurements are in micrometers, unless otherwise indicated. Classification of the nematodes is in accord to Chabaud (1975) and host species to Schauensee (1970). NHR refers to new host record.

\section{RESULTS}

Schistorophus molini n. sp.

Figs 1-4, 11, 12

(Acuarioidea, Acuariidae, Schistorophinae)

Description: morphometrics based on three mature specimens, one male and two females (one incomplete).

General: ptilina as four bi-lobed well developed shields, 82-140 long. Buccal capsule 61-72 long, lined with transversely striated cuticle. Esophagus divided in two portions, the anterior muscular, the posterior glandular.

Male (Figs 1, 2, 4, 10, 11): body $9.55 \mathrm{~mm}$ long, 180 wide. Muscular and glandular esophagus 0.72 and $1.19 \mathrm{~mm}$ long, respectively. Nerve ring 180 from anterior extremity. Caudal region tightly coiled. Caudal alae well developed with 13 pairs of precloacal and five pairs of postcloacal pedunculated caudal papillae, the last pair of postcloacal smaller than the rest. Spicules unequal and dissimilar. Left spicule slender, 460 long, with round tip, lacking distal process; right spicule stout, 120 long, with a triangular expansion near round distal end. Tail short with a pair of phasmids at its tip. 
Females (Figs 3, 12): body $14.28 \mathrm{~mm}$ long, 280-300 wide. Muscular and glandular esophagus 0.95-1.20 and 0.95-1.32 mm long, respectively. Nerve ring 250310 from anterior extremity. Vulva located at 6.48 $\mathrm{mm}$ from posterior extremity. Vagina lined with cuticle and surrounded by thick muscle fibers, divided unequally into vagina vera and vagina uterina, 50 and 250 long, respectively. Didelphic, amphidelphic. Uteri with larvated, thick- shelled eggs, 28-30 long and 14-16 wide. Rectum 100 long. Anus 72 from posterior end. Tail blunt, with round tip.

Taxonomic summary

Type host: Laterallus viridis (Müller, 1776) [= Rallus cayennensis (Gmelin)]; common names: russetcrowned crake; "siricora-mirim, sanã, pinto-d'água". Site of infection: gizzard.

Type locality: Brazil (according to original files).

Date: 1 November, 1909.

Etymology: the new species is named after R Molin, a distinguished helminthologist in the 19th century. Studied type material: CHIOC no. 33,948a - holotype; $33,948 \mathrm{~b}$ - alotype; $33,948 \mathrm{c}$ - paratype (whole mounts).

Remarks

The species of Schistorophus Railliet, 1916 are reported parasitizing Charadriidae, Recurvirostridae and Scolopacidae waders. The genus was revised (Wong \& Lankester 1984) and five species were recognized: S. longicornis (Hemprich \& Ehrenberg, 1866) Railliet, 1916, S. skrjabini (Vassilkova, 1926) Guschanskaya, 1950, S. cirripedesmi Rhizhikov \& Khokhlova, 1964, S. cornutus Sobolev, 1943 and S. guschanskoi Ablasov \& Chibichenko, 1962.

S. molini n. sp., proposed herein, is compared to these species taking into account the most reliable characters used in their identification (Table).

$S$. cirripedesmi is the most closely related species to $S$. molini $\mathrm{n}$. sp. as indicated by the length of ptilina and spicules. Although the length of ptilina and spicules of both species are similar, the presence of a distal process in the left spicule of the former and the different ratios of the vagina vera to

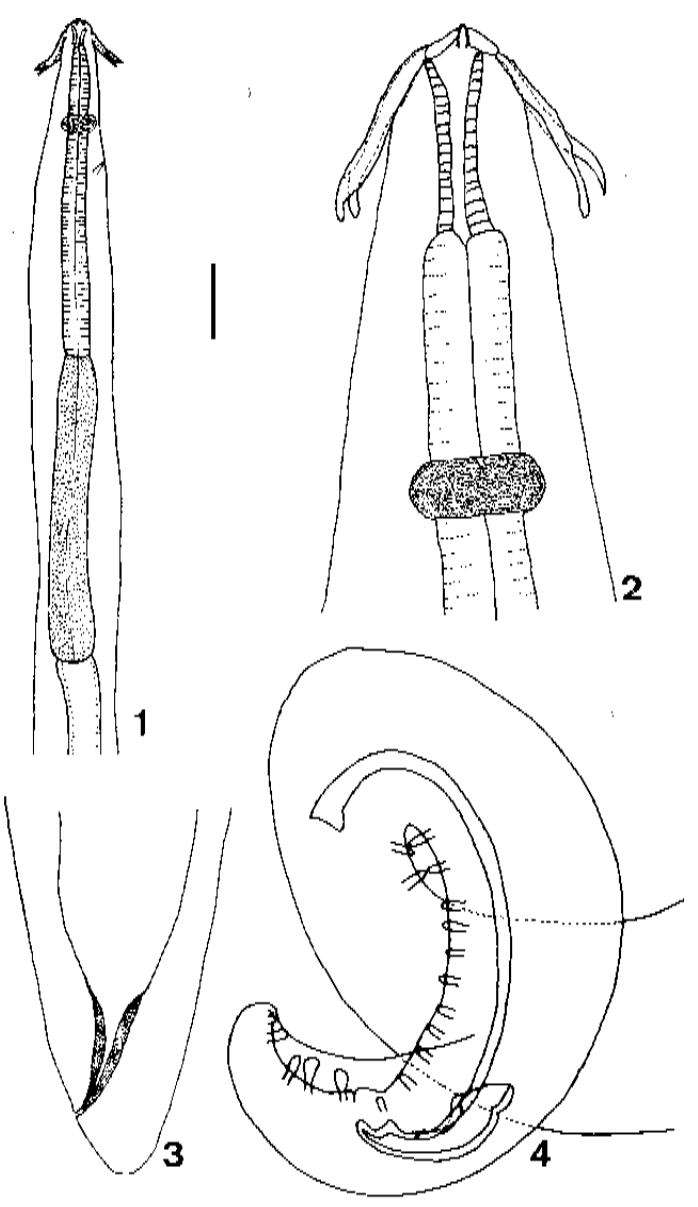

Schistorophus molini n. sp. - Fig. 1: anterior portion of male, lateral view. Fig. 2: anterior extremity of male, lateral view. Fig. 3: posterior extremity of female, lateral view. Fig. 4: posterior portion of male, lateral view. Bar common to all figs. Fig. $1=0.1$; Fig. $2=0.02$; Figs $3,4=$ $0.05 \mathrm{~mm}$

the vagina uterina in females of $S$. molini $\mathrm{n}$. sp. (Fig. 12) and S. cirripedesmi (1:5 and 1:4, respectively), are reliable parameters to promptly distinguish the species. Although the generic diagnosis

TABLE

Comparative data on Schistorophus spp.

\begin{tabular}{|c|c|c|c|c|c|c|c|}
\hline \multirow[t]{2}{*}{ Species } & \multirow[t]{2}{*}{$\begin{array}{l}\text { Length of } \\
\text { ptilina }\end{array}$} & \multicolumn{2}{|c|}{$\begin{array}{l}\text { Length of } \\
\text { spicules }\end{array}$} & \multirow{2}{*}{$\begin{array}{l}\text { Process (es) on } \\
\text { distal end of } \\
\text { left spicule }\end{array}$} & \multicolumn{2}{|c|}{$\begin{array}{c}\text { Length of } \\
\text { vagina }\end{array}$} & \multirow[t]{2}{*}{ Host order } \\
\hline & & Right & Left & & Vera & Uterina & \\
\hline S. cirripedesmi & $50-125$ & 140 & 540 & present & 120 & 480 & Charadriiformes \\
\hline S. cornutus & $60-75$ & $120-169$ & $270-230$ & $?$ & $?$ & $?$ & Charadriiformes \\
\hline S. guschanskoi & $220-290$ & $120-126$ & $710-940$ & $?$ & $?$ & $?$ & Charadriiformes \\
\hline S. longicornis & $25-40$ & 150 & 1250 & absent & 46 & 773 & $\begin{array}{l}\text { Charadriiformes } \\
\text { Caprimulgiformes }\end{array}$ \\
\hline S. skrjabini & $170-400$ & $105-150$ & $400-600$ & present & 154 & 105 & Charadriiformes \\
\hline S. molini n. sp. & $82-140$ & $120-460$ & 460 & absent & 50 & 250 & Gruiformes \\
\hline
\end{tabular}


of Schistorophus refers to "...four ptilina in form of delicate horns with pointed tips...", our specimens show a somewhat different pattern of arrangement in which the four ptilina are bi-lobed presenting eight wing-like projections (Figs 10,11) and these identations are actually regarded as a specific character. S. molini n. sp. was not designed as $S$. laciniatus (Molin, 1860b) Railliet, 1916, considering that Cram (1927) refers to very few and inconclusive morphological data on S. laciniatus, only related to body length and width in both sexes, number of caudal papillae in the male and localization of the vulvar opening and geographical distribution (South America, Brazil). Although Vicente et al. (1995), not aware of the early paper by Wong and Lankester (1984), include S. laciniatus as a valid species in a general survey on nematodes from Brazilian birds, we fully agree with Wong and Lankester (1984) in the statement that S. laciniatus is to be referred to as a species inquirendae. It was described as Histiocephalus laciniatus, based on specimens recovered from the same host of $S$. molini n. sp., Laterallus viridis (= Rallus cayennensis) in South America, but the types were lost, the original description is incomplete and no illustrations are provided. Nevertheless, Wong and Lankester (1984) misinterpreted the taxonomic status of the original host, when they reported Belonopterus chilensis cayennensis (Gmelin, 1789) as the synonym for Rallus cayennensis (Gmelin) Sharpe, 1894, instead of Laterallus viridis (Müller, 1776).

Key to the species of Schistorophus Railliet, 1916

In order to complement the present findings, a key to the species of Schistorophus, modified and adapted after Wong and Lankester (1984) is presented.

1a. ptilina shorter than $50 \mu \mathrm{m}$, left spicule longer than $1.0 \mu \mathrm{m}$. S. longicornis

b. otherwise. .....2

2a. ptilina 50-200 mm long............................

b. length of ptilina longer than $200 \mathrm{~mm}$......................5

3a. left spicule shorter than $450 \mathrm{~mm}$, male with 12 pairs of precloacal papillae.................. S. cornutus b. left spicule longer than $450 \mathrm{~mm}$.

$4 \mathrm{a}$. vagina vera $1 / 5$ of the length of the vagina uterina, 13 pairs of precloacal papillae, four bi-lobed ptilina.................................... S. molinin. sp. b. vagina vera $1 / 4$ of the length of the vagina uterina, 15-22 pairs of precloacal papillae

5a. left spicule longer than $700 \mathrm{~mm}$ S. cirripedesmi ..S. guschanskoi b. left spicule shorter than $700 \mathrm{~mm}$........S. skrjabini

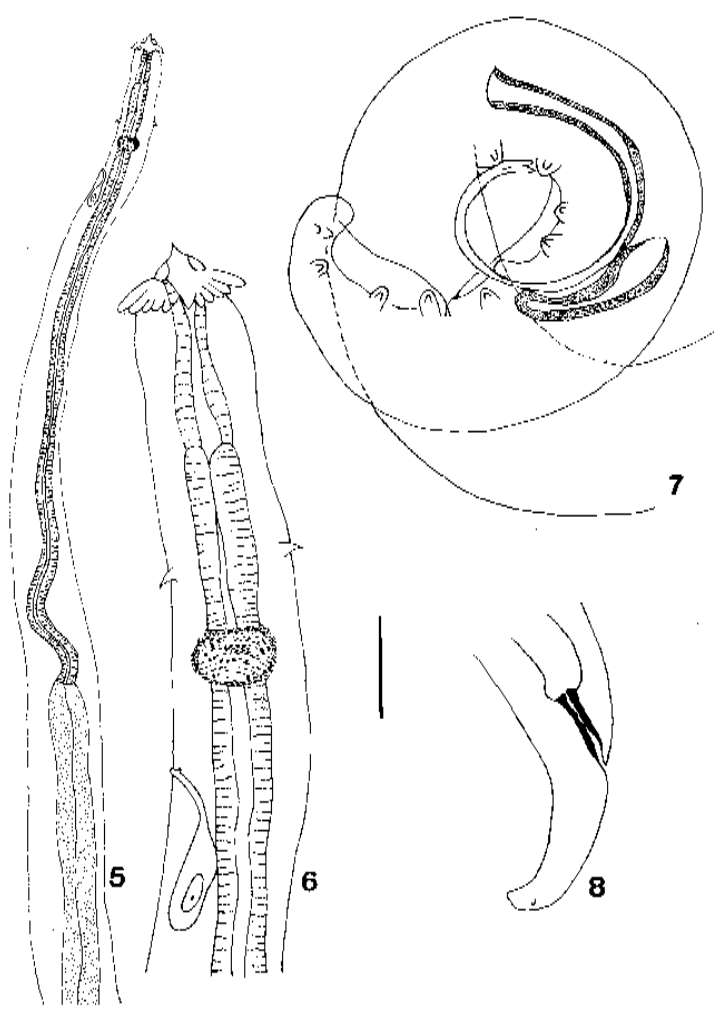

Ancyracanthopsis coronata - Fig. 5: anterior portion of male, lateral view. Fig. 6: anterior extremity of male, lateral view. Fig. 7: posterior portion of male, lateral view. Fig. 8: posterior extremity of female, lateral view. Bar common to all figs. Figs $5,8=0.1$, Fig. $6=0.03$, Fig. $7=$ $0.05 \mathrm{~mm}$.

\section{Ancyracanthopsis coronata (Molin, 1860) Chabaud \& Petter, 1959 \\ (Acuarioidea, Acuariidae, Schistorophinae) Figs 5-10}

Redescription based on ten mature specimens, five males and five females. General: ptilina present. Each divided into 4-5 equal lobes, 14-18 long. Buccal capsule 46-61 long, expanded anteriorly and lined with transversely striated cuticle. Deirids medium-sized, located anterior to nerve ring. Muscular portion of esophagus about one-third length of glandular esophagus.

Males (Figs 5, 6, 7): body 6.30-7.14 mm long, 110-140 wide. Muscular and glandular esophagus 700-790 and 1.68-1.96 mm long, respectively. Nerve ring 120-130 from anterior extremity. Caudal region with ventral curve. Caudal alae prominent, bearing four pairs of preacloacal and five pairs of postcloacal, pedunculated caudal papillae. Spicules unequal and dissimilar. Right spicule stout, crescent-shaped, 82-90 long. Left spicule slender, elongate, with distal bifurcate end, 220-300 long. Cloaca 79-90 from posterior extremity. Tail with round tip. 

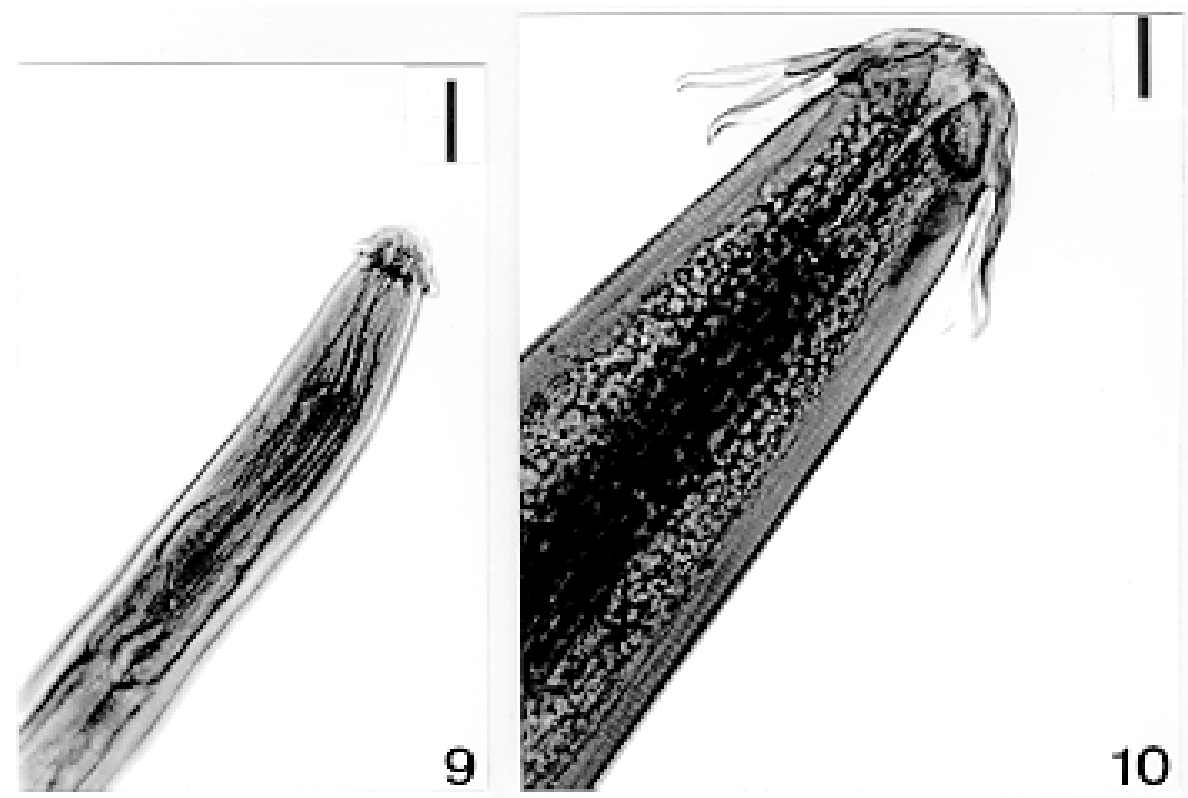

Ancyracanthopsis coronata - Fig. 9: anterior extremity of male, lateral view. Bar $=0.02 \mathrm{~mm}$. Schistorophus molini $\mathrm{n}$. sp. - Fig. 10: anterior extremity of male, lateral view. Bar $=0.02 \mathrm{~mm}$.
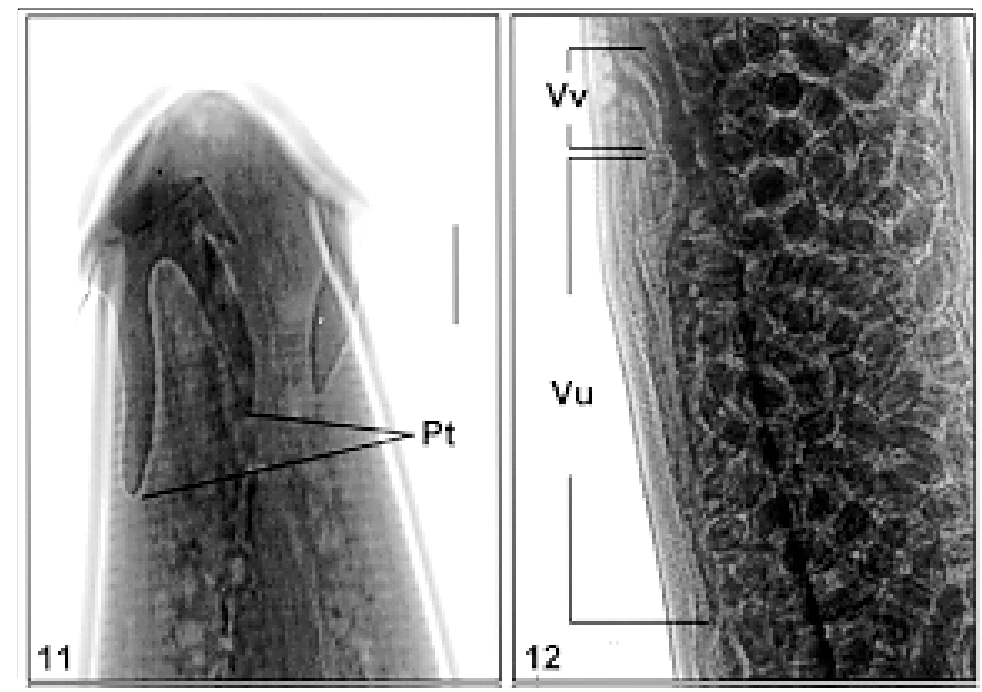

Schistorophus molini $\mathrm{n}$. sp. - Fig. 11: anterior extremity of male, showing bi-lobed dorsal ptilinum (Pt), lateral view. Fig. 12: female, showing terminal genitalia (Vv: vagina vera; Vu: vagina uterina), lateral view. Bar common to both figs. Fig. $11=0.01 \mathrm{~mm}$; Fig. $12=0.04 \mathrm{~mm}$.

Females (Figs 8, 9): body 11.90-12.58 mm long, 120-140 wide. Muscular and glandular esophagus 640-840 and 1.68-2.2.03 mm long, respectively. Nerve ring 110-130 from anterior extremity. Vulva located at 7.14-8.16 mm from anterior extremity. Vagina surrounded by muscle fibers. Didelphic, amphidelphic. Uteri packed with larvated, thick-shelled eggs, 3639 long, 21-25 wide. Rectum 72-90 long. Anus 150-
180 from posterior extremity.

Taxonomic summary

Host: Aramides mangle (Spix, 1825) - NHR; common names: little wood rail; "saracura-do-mangue, saracura-da-praia".

Site of infection: gizzard.

Locality: Rio de Janeiro, RJ, Brazil.

Date: 28 August, 1940. 
Studied material: CHIOC no. 33,949 a-d (whole mounts); 13,665 (wet material).

\section{REMARKS}

These are the first morphometric data on $A$. coronata based on Brazilian well preserved samples. The specimens studied by Molin (1860 a) and recovered from the kingfisher Chlroceryle americana (Gmelin) and the southern lapwing Vanellus chilensis cayennensis (Gmelin) in Brazil, are presumably lost, considering that the bottle labelled as types of $A$. coronata contained only a head region and a midbody section of a nematode (Wong \& Lankester 1985).

Although another species of the genus, $A$. bilabiatus, described also by Molin (1860 b) from the Brazilian surfbird Eurypyga helias (Pallas) is considered a junior synonym of $A$. coronata, designated as the type species of the genus, the original sample of A. bilabiatus consists of three larvae, three body sections and one adult female only (Wong \& Lankester 1985).

A. coronata has been recorded in the Americas and Europe in Charadriiformes, Ciconiiformes, Gruiformes and Passeriformes birds.

\section{ACKNOWLEDGEMENTS}

To Dr Marinete Amorim, Laboratório de Ixodides, Departamento de Entomologia, to the Setor de Multimeios and to Heloisa Diniz, Laboratório de Produção e Processamento de Imagens, Instituto Oswaldo Cruz for technical assistance regarding figures.

To Prof. Jorge Bruno Nacinovic and Prof. Dante Martins Teixeira, Seção de Ornitologia, Museu Nacional do Rio de Janeiro, Universidade Federal do Rio de Janeiro for data on the taxonomic status of the hosts.

\section{REFERENCES}

Chabaud AG 1975. Keys to the genera of the order Spirurida. Spiruroidea, Habronematoidea and Acuariodea, p. 29-58. In RC Anderson, AG Chabaud \& S Willmot (eds), CHI Keys to the Nematode Parasites of Vertebrates 3, Part 2, Commonwealth Agricultural Bureaux, England.

Cram EB 1927. Bird parasites of nematode suborders Strongylata, Ascaridata and Spirurata. US Nat Mus 140: $1-465$.

Molin R 1860a. Una monografia del genera Spiroptera. Sitzungsber Kais Akad Wiss Wien Math Naturwiss Kl 38: 911-1005.

Molin R 1860b. Trenta specie di nematoide. Sitzungsber Kais Akad Wiss Wien Math Naturwiss Kl 40: 331-358.

Pinto RM, Vicente JJ 1995. Tetrameres (Tetrameres) spirospiculum $\mathrm{n}$. sp. (Nematoda, Tetrameridae) from the buff-necked ibis, Theristicus caudatus caudatus (Boddaert) (Aves, Threskiornithidae). Mem Inst Oswaldo Cruz 90: 615-617.

Pinto RM, Vicente JJ, Noronha D 1993. Nematode parasites of Brazilian psittacid birds, with emphasis on the genus Pelecitus Railliet \& Henry, 1910. Mem Inst Oswaldo Cruz 88: 279-284.

Schauensee RM 1970. A Guide to the Birds of South America, Oliver \& Boyd, Edinburgh, Scotland, 470 pp.

Vicente JJ, Rodrigues HO, Gomes DC, Pinto RM 1995. Nematóides do Brasil. Parte IV: Nematóides de aves. Revta bras Zool 12 (Supl. 1): 1-273.

Wong PL, Lankester MN 1984. Revision of the genus Schistorophus Railliet, 1916 (Nematoda: Acuarioidea). Can J Zool 62: 2527-2540.

Wong PL, Lankester MN 1985. Revision of the genus Ancyracanthopsis Diesing, 1861 and description of a new genus Molinacuaria n. gen. (Nematoda: Acuarioidea). Can J Zool 63: 1556-1564. 